Niigata, Japan

\title{
Disappearance of the Difference between Adrenal A and NA Cells in the Level of Radioactivity after ${ }^{3} \mathrm{H}$-Dopa Injection in the Hypophysectomized Mouse
}

\author{
Shigeru Kobayashi, Kentaro Goto and Kenichi Kano
}

Received January 20, 1978

\begin{abstract}
Summary. Radioactivity in adrenal medullary chromaffin cells of the mouse was examined by autoradiographic methods $15 \mathrm{~min}$ to $1 \mathrm{hr}$ after an intraperitoneal injection of ${ }^{3} \mathrm{H}$-dopa. In the normal control mice, the concentration of radioactivity was significantly higher in the A cells than in the NA cells, whereas in the hypophysectomized mice ( 9 days after operation by the transauricular method) the radioactivity was evenly distributed in the two cell types. It was suggested that both $A$ and $N A$ cells possessed a special trapping and concentrating mechanism for extracellular dopa and/or its metabolites and that the activity of this mechanism was made greater in the A cells than in the NA cells by the pituitary gland.
\end{abstract}

There seems to be fairly ample biochemical data showing that the pituitary hormones control the enzyme activities of the biosynthetic pathway of catecholamines in the adrenal chromaffin cells (see PoHORECKy and Wurtman, 1971). Especially, phenylethanolamine- $\mathrm{N}$-methyl transferase activity, contained solely in the A cells, is greatly suppressed in hypophysectomized rats (WURTMAN and AxELROD, 1966). This may suggest that the pituitary influence on the A cells may be different from that on the NA cells. In the present study, we investigated by autoradiography the effects of hypophysectomy on the established phenomenon that the adrenal A cells accumulate higher radioactivity than the NA cells after ${ }^{3} \mathrm{H}$-dopa injection (ELfvin, Appelgren and Ullberg, 1966; Coupland, Kobayashi and Crowe, 1976).

\section{Materials and Methods}

Adult male mice of dd-strain were used in this study. They were supplied by the Teikoku-Zoki Co. Ltd., Tokyo. Hypophysectomy was performed by the transauricular method (FALCONI and Rossi, 1964) at the age of 10 weeks. Nine days after the operation, hypophysectomized mice were used for the autoradiographic study.

L-3, 4-dihydroxy (ring-G- ${ }^{3} \mathrm{H}$ ) phenylalanine ( ${ }^{3} \mathrm{H}$-dopa) purchased from the Radiochemical Center, Amersham, England was injected into the peritoneal cavity of the mouse $(10 \mu \mathrm{Ci} /$ g.b.w.). Thirty min after the injection, a fixative, 2.5 percent glutaraldehyde in a $0.1 \mathrm{M}$ phosphate buffer at $\mathrm{pH} 7.2-7.4$, was perfused from the left ventricle of the heart. Adrenal glands were removed and further fixed in the same glutaraldehyde solution overnight. Post-osmication, dehydration and resin-embedding were done as mentioned elsewhere (Coupland, Kobayashi and CROwe, 1976). Semi-thin sections were cut on a Porter-Blum MT1 ultramicrotome and mounted on gelatin-coated glass slides. An emulsion layer was applied by the dipping method 
using Ilford L4 emulsion. The developer used was D-19. Autoradiograms were stained with 0.5 percent toluidine blue after photographic processing.

A few supplementary autoradiograms of the ${ }^{3} \mathrm{H}$-dopa injected adrenal glands were also examined as listed in Table $1(\mathrm{I}-\mathrm{V})$. These autoradiograms were prepared from normal adult male mice of either CS1- or dd-strain $15 \mathrm{~min}$ to $1 \mathrm{hr}$ after an intraperitoneal injection of ${ }^{3} \mathrm{H}$-dopa $(10-50 \mu \mathrm{Ci} / \mathrm{g} . \mathrm{b} . w$.$) . After perfusion-fixation with$ glutaraldehyde followed by post-osmication, dehydration and resin-embedding, autoradiograms were made by a dipping method using Ilford G5 or L4 emulsion.

Grain counting of the autoradiograms was performed using an eye piece graticule. Silver grains were visually counted and expressed as the number of silver grains over a unit area of the autoradiogram.

\section{Results}

Reduction of the size of the adrenal gland and the atrophy of the cortical tissue after hypophysectomy were clear in the light microscopic observation of the adrenal sections of the hypophysectomized mice. Thus, it was confirmed that the pituitary gland was really removed.

In both intact control and hypophysectomized mice, the majority of the chromaffin cells in the adrenal medulla were A cells, whereas NA cells occupied about 30 percent of the total population of the chromaffin cells. The SGC cells which have recently been distinguished from the $A$ and NA cells by the electron microscopic method (KoBAYASHI and Coupland, 1977) were included in the category of NA cells, because the light microscopic distinction between the NA and SGC cells was practic-

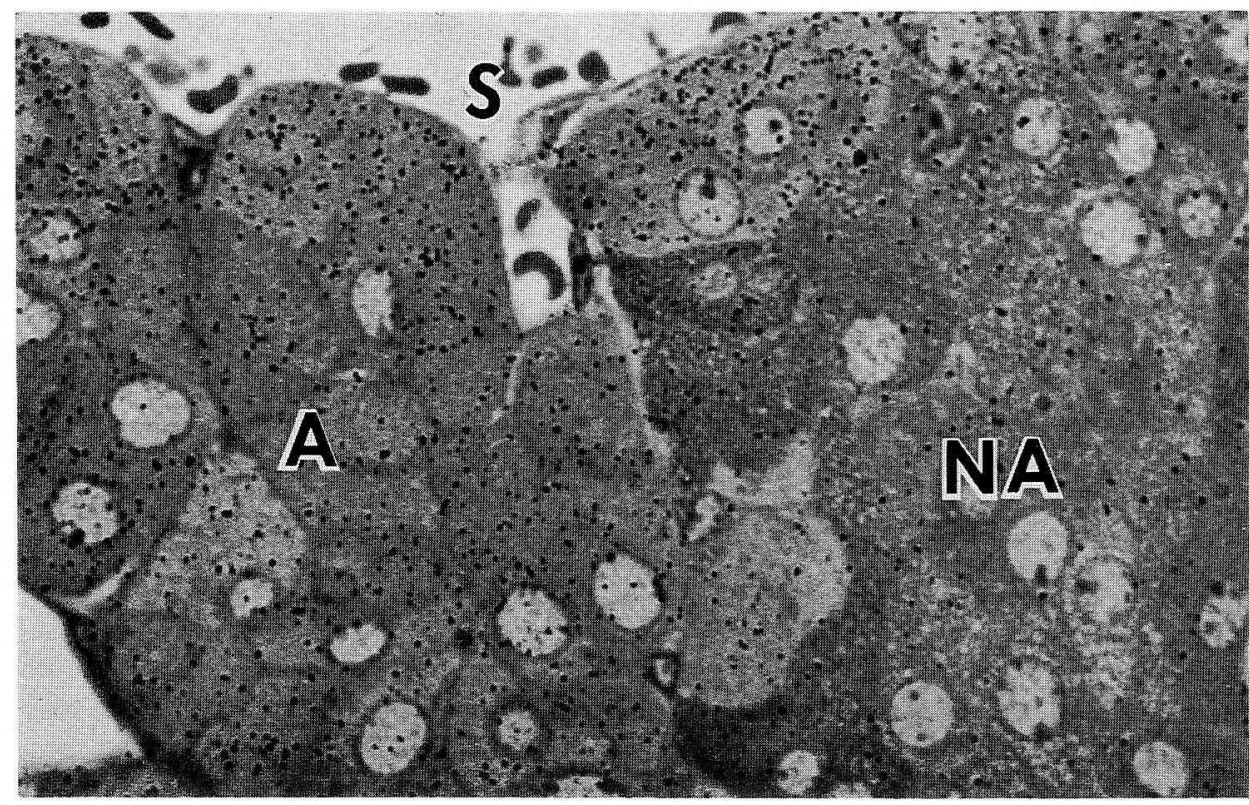

Fig. 1. Autoradiogram of the adrenal medulla of a normal control mouse 30 min after the injection of $10 \mu \mathrm{Ci} / \mathrm{g}$. b.w. ${ }^{3} \mathrm{H}$-dopa. Notice that grain density over A cell group $(A)$ (937 in $\left.4,500 \mu \mathrm{m}^{2}\right)$ is higher than that on the NA cell group $(N A)\left(238\right.$ in $\left.3,200 \mu \mathrm{m}^{2}\right)$. S sinusoidal lumen. Autoradiogram exposed for 9 days. $\times 1,100$ 


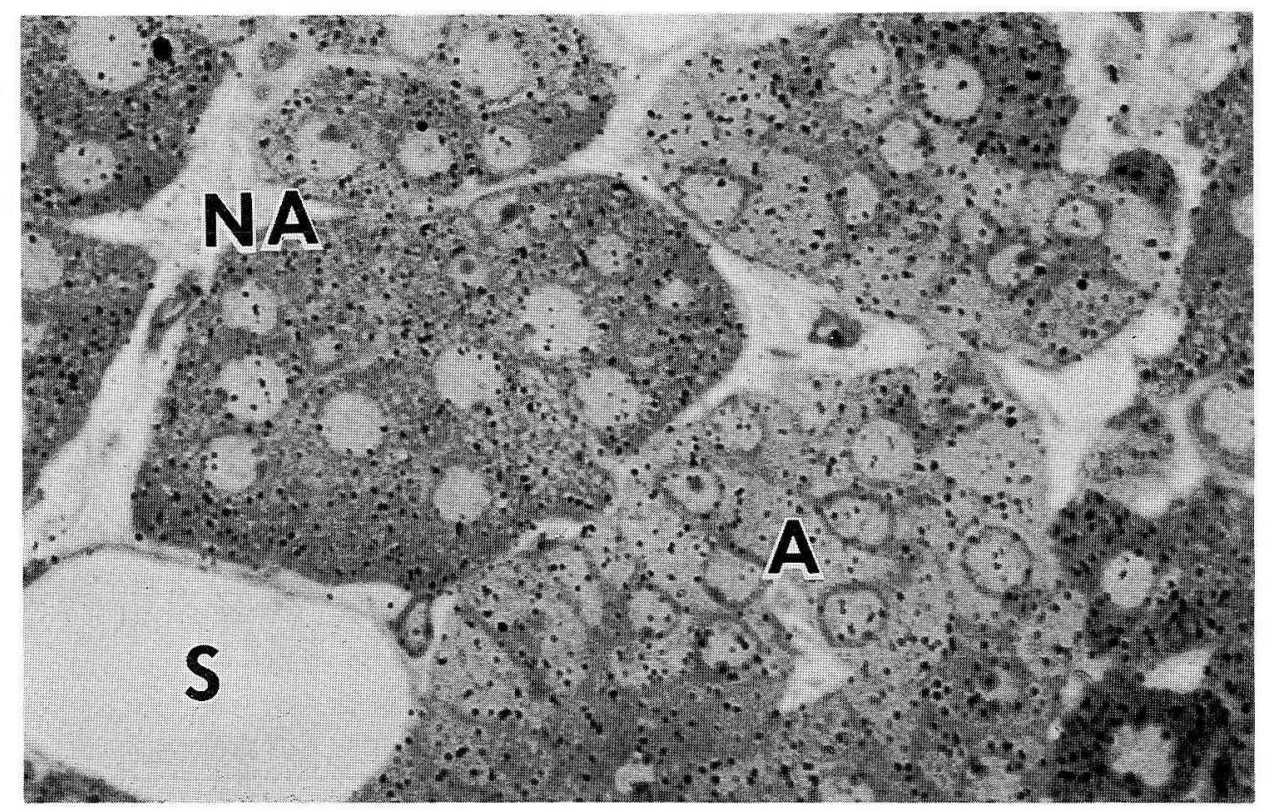

Fig. 2. Autoradiogram of the adrenal medulla of a hypophysectomized mouse ( 9 days after operation) $30 \mathrm{~min}$ after the injection of $10 \mu \mathrm{Ci} / \mathrm{g}$.b.w. ${ }^{3} \mathrm{H}$-dopa. Grain densities on A cell group (738 in $3,200 \mu \mathrm{m}^{2}$ ) and NA cell group (834 in $3,600 \mu \mathrm{m}^{2}$ ) are nearly equal. Autoradiogram exposed for 9 days. $\times 1,100$

ally impossible in the toluidine blue-stained specimen.

In the autoradiograms of both intact control and hypophysectomized adrenal glands, chromaffin cells were heavily labeled by specific silver grains which indicated the presence of ${ }^{3} \mathrm{H}$-dopa and its metabolites. The specific silver grains on the adrenal cortical cells, capillary endothelial cells and connective tissue cells in the subendothelial space were very few (Fig. 1, 2).

In the normal control mice, the grain density on the A cells was conspicuously higher than that on the NA cells (Fig. 1). On the other hand, in all three hypophysectomized mice, the specific silver grains were distributed fairly evenly throughout the adrenal medulla: The difference between the $\mathrm{A}$ and NA cells with regard to the density of the specific silver grains was obscure (Fig. 2).

To confirm these visual observations, grain-counting was performed. The number of silver grains per unit area of autoradiograms occupied by each chromaffin cell type was counted using an eye piece graticule. Special care was taken to grain-count ten or more fields which were selected at random, because there was a slight tendency in the normal control mice for chromaffin cells near the capillary lumen to be more heavily labeled by the specific silver grains than those apart from it.

Results of grain-counting shown in Table 1 indicate that there was no difference in the concentration of ${ }^{3} \mathrm{H}$-dopa-derived radioactivity between the $\mathrm{A}$ and $\mathrm{NA}$ cells in the hypophysectomized mice. In the normal control mice, radioactivity over the unit area of the autoradiograms was 1.4 to 2.3 times higher in the A cells than in the NA cells, whereas in the three mice sacrificed 9 days after hypophysectomy the ratio 
Table 1. Grain densities over adrenal A and NA cells after an intraperitoneal injection of ${ }^{3} \mathrm{H}$-dopa

\begin{tabular}{|c|c|c|c|c|c|c|c|}
\hline \multirow{2}{*}{ Mice (Strain) } & \multirow{2}{*}{$\begin{array}{c}\text { Dose } \\
(\mu \mathrm{Ci} / \text { g.b.w. })\end{array}$} & \multirow{2}{*}{$\begin{array}{l}\text { Emulsion } \\
\text { used }\end{array}$} & \multirow{2}{*}{$\begin{array}{l}\text { Exposure } \\
\text { (days) }\end{array}$} & \multicolumn{2}{|c|}{$\begin{array}{l}\text { Silver grains } / 225 \mu \mathrm{m}^{2} \\
\quad(\text { Mean } \pm \text { S.E. })\end{array}$} & \multirow{2}{*}{$\begin{array}{l}\text { Ratio of } \\
\text { grain } \\
\text { counts } \\
\text { A/NA }\end{array}$} & \multirow{2}{*}{$\begin{array}{c}\text { Time } \\
\text { after } \\
\text { labeling } \\
\text { (min) }\end{array}$} \\
\hline & & & & A cell & NA cell & & \\
\hline \multicolumn{8}{|l|}{ Normal control } \\
\hline I $\quad(\mathrm{CS} 1)$ & 10 & G5 & 14 & $52.7 \pm 3.3$ & $25.8 \pm 1.7$ & 2.0 & 15 \\
\hline II (CS1) & 10 & G5 & 14 & $51.3 \pm 3.9$ & $22.3 \pm 1.9$ & 2.3 & 30 \\
\hline III (CS1) & 10 & G5 & 14 & $77.8 \pm 6.0$ & 41. $1 \pm 2.8$ & 1.9 & 60 \\
\hline IV (dd) & 50 & L 4 & 12 & $95.0 \pm 5.0$ & 52. $4 \pm 3.7$ & 1.8 & 60 \\
\hline $\mathrm{V} \quad(\mathrm{CS} 1)$ & 50 & G5 & 5 & 83. $0 \pm 3.5$ & 41. $3 \pm 3.0$ & 2. 0 & 60 \\
\hline$* \mathrm{VI} \quad(\mathrm{dd})$ & 10 & $\mathrm{~L}_{4}$ & 9 & $60.6 \pm 4.2$ & $38.0 \pm 2.6$ & 1.6 & 30 \\
\hline$* \mathrm{VI} \quad(\mathrm{dd})$ & 10 & $\mathrm{~L} 4$ & 9 & 39. $6 \pm 3.1$ & 28. $1 \pm 2.3$ & 1. 4 & 30 \\
\hline \multicolumn{8}{|c|}{ Hypophysectomized } \\
\hline$* \mathrm{I} \quad(\mathrm{dd})$ & 10 & L 4 & 9 & 43. $3 \pm 2.2$ & $42.9 \pm 2.6$ & 1. 0 & 30 \\
\hline$*$ II $\quad(\mathrm{dd})$ & 10 & $\mathrm{~L} 4$ & 9 & $52.9 \pm 2.4$ & 48. $6 \pm 2.9$ & 1.1 & 30 \\
\hline$*$ III $(\mathrm{dd})$ & 10 & L 4 & 9 & 46. $5 \pm 2.4$ & 45. $7 \pm 4.7$ & 1. 0 & 30 \\
\hline
\end{tabular}

* Data collected from a batch of autoradiograms mounted on a single glass slide.

of radioactivity on the A cells to that on the NA cells was in the range between 1.0 and 1.1. The results of grain-counting also show that the absolute amount of radioactivity after ${ }^{3} \mathrm{H}$-dopa injection in both $\mathrm{A}$ and $\mathrm{NA}$ cells was not markedly reduced after hypophysectomy.

\section{Discussion}

ELFVIN and associates (1966) first demonstrated that radioactivity in the adrenal A cells was significantly higher than that in the NA cells 30 min after the administration of ${ }^{3} \mathrm{H}$-dopa in the mouse and hamster. This was confirmed by Coupland and associates (1976) in their recent studies in the mouse, although the causes of this phenomenon have remained unknown. In the present study it was shown that this difference in the level of ${ }^{3} \mathrm{H}$-dopa-derived radioactivity between the two types of adrenal chromaffin cells was absent in the hypophysectomized mice. Therefore, it may be concluded that the pituitary gland is essential to cause a higher accumulation of radioactivity in the adrenal A cells than in the NA cells after ${ }^{3} \mathrm{H}$-dopa injection.

It has been demonstrated using the chromatographic technique that radioactivity in the mouse adrenal medulla $5 \mathrm{~min}$ to $1 \mathrm{hr}$ after an intraperitoneal administration of ${ }^{3} \mathrm{H}$-dopa is mainly accounted for by ${ }^{3} \mathrm{H}$-dopamine and ${ }^{3} \mathrm{H}$-noradrenaline (Coupland, KoBAYASHI and CROWE, 1976). Thus, most of the specific silver grains observed in the present study probably represented ${ }^{3} \mathrm{H}$-dopamine and ${ }^{3} \mathrm{H}$-noradrenaline. It is also known that dopa-decarboxylase which converts dopa into dopamine is contained not only in the adrenal medulla but also in various organs of the body including the liver and kidney (Lovenberg, WeIssbach and Udenfriend, 1962). Therefore, ${ }^{3} \mathrm{H}$-dopa injected into the peritoneal cavity could have been converted into ${ }^{3} \mathrm{H}$-dopamine when it reached the adrenal medulla. 
The catecholamine-secreting function of the adrenal chromaffin cells is a chain of processes including the following three steps: ingestion of precursors, synthesis of catecholamines and extrusion. Previous biochemical studies have shown that hypophysectomy suppresses such enzyme activities involved in the biosynthesis of catecholamines as tyrosine hydroxylase, dopamine- $\beta$-hydroxylase and phenylethanolamine-N-methyl transferase (Wurtman and AxELrod, 1966; see also PoHorecky and Wurtman, 1971). However, it seems difficult to explain the results of the present autoradiographic study by the removal of the pituitary effect on the process of catecholamine synthesis, because the level of ${ }^{3} \mathrm{H}$-dopa-derived radioactivity will remain constant, whether or not ${ }^{3} \mathrm{H}$-dopa is converted into ${ }^{3} \mathrm{H}$-dopamine, ${ }^{3} \mathrm{H}$-noradrenaline and ${ }^{3} \mathrm{H}$-adrenaline. The results of the present study suggest that both $\mathrm{A}$ and NA cells of the adrenal medulla possess a special trapping and concentrating mechanism for extracellular dopa and/or its metabolites: The capacity of this uptaking mechanism may be better developed in the A cells than in the NA cells under the control of the pituitary gland: In the absence of the pituitary gland, this difference between the two types of chromaffin cells disappears so that radioactivity after ${ }^{3} \mathrm{H}$ dopa injection is distributed fairly evenly throughout the adrenal medulla in the hypophysectomized mice.

Biochemical studies have also shown that the suppressed activity of phenylethanolamine-N-methyl transferase in the adrenal medulla of the hypophysectomized animals recovered by the administration of either pituitary ACTH or adrenal glucocorticoids (see Pohorecky and Wurtman, 1971). These biochemical data seem to suggest that autoradiographic studies in the hypophysectomized mice using ACTH and/or glucocorticoids might be useful to investigate further the pituitary control on the activities of the trapping and concentrating mechanism for exogenous dopa and its metabolites in different types of adrenal chromaffin cells.

\section{${ }^{3} \mathbf{H}-$ ドパ 投与マウスの副腎髄質 $\mathbf{A}$ 細胞と NA 細胞の放射能差の 下垂体剔出による消失}

小林 繁, 後藤 健太郎, 狩野 健一

${ }^{3} \mathrm{H}-ト ゙$ パ腹腔内投与後 15 分から 1 時間の マウス副腎髄質のクロム親和細胞内での放射 能について, オートラジオグラフィーを使って調べたところ, 対照群の正常マウスでは A 細胞の放射能が NA 細胞のそれより有意に高かったが，下垂体剔出（経耳法）9 日後のマ ウスでは，これら両型のクロム親和細胞に含まれる放射能はほぼ同様であった. この結 果より，クロム親和細胞には 外来性ドパまたはその代謝産物に対する 特別の取りこみ機 構があり，この機構が A 細胞では NA 細胞におけるよりも活発に作動するように下垂体 が支配している可能性が考えられた。 


\section{References}

Coupland, R. E., S. Kobayashi and J. Crowe: On the fixation of catecholamines including adrenaline in tissue sections. J. Anat. 122: 403-413 (1976).

Elfvin, L.-G., L. E. Appelgren and S. Ullberg : High-resolution autoradiography of the adrenal medulla after injection of tritiated dihydroxyphenyl alanine (Dopa). J. Ultrastr. Res. 14: 277-293 (1966).

Falconi, G. and G. L. Rossi : Transauricular hypophysectomy in rats and mice. Endocrinology 74: 301-303 (1964).

Kobayashi, S. and R. E. Coupland : Two populations of microvesicles in the SGC (Small Granule Chromaffin) cells of the mouse adrenal medulla. Arch. histol. jap. 40: 251-259 (1977).

Lovenberg, W., H. Weissbach and S. Udenfriend: Aromatic L-amino acid decarboxylase. J. biol. Chem. 237: 89-93 (1962).

Pohorecky, L. A. and R. J. Wurtman : Adrenocortical control of epinephrine synthesis. Pharmacol. Rev. 23: 1-35 (1971).

Wurtman, R. J. and J. Axelrod : Control of enzymatic synthesis of adrenaline in the adrenal medulla by adrenal cortical steroid. J. biol. Chem. 241: 2301-2305 (1966).

小林 繁

勇951 新潟市旭町通 1

新潟大学医学部

第三解剖学教室
Dr. Shigeru Kobay ASHI

Department of Anatomy

Niigata University School of Medicine

Niigata, 951 Japan 